\title{
Working
}

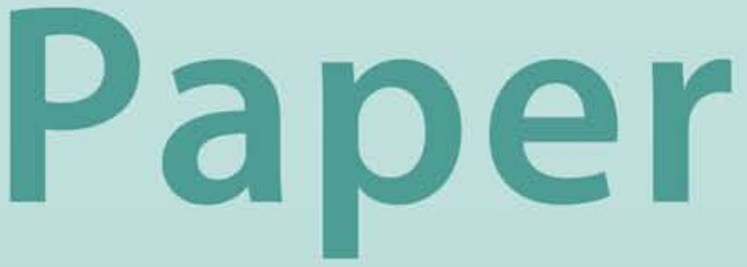


Hedging Foreign Exchange Risk in Chile: Markets and Instruments

\author{
Jorge A. Chan-Lau
}




\title{
IMF Working Paper \\ International Capital Markets Department
}

\section{Hedging Foreign Exchange Risk in Chile: Markets and Instruments ${ }^{1}$}

\author{
Prepared by Jorge A. Chan-Lau \\ Authorized for distribution by David J. Ordoobadi
}

February 2005

\begin{abstract}

\section{This Working Paper should not be reported as representing the views of the IMF.} The views expressed in this Working Paper are those of the author(s) and do not necessarily represent those of the IMF or IMF policy. Working Papers describe research in progress by the author(s) and are published to elicit comments and to further debate.
\end{abstract}

Policy makers have expressed interest in fostering the development of local foreign exchange derivatives markets with a view to reducing risks arising from currency mismatches between assets and liabilities in the corporate sector. This paper assesses foreign exchange exposure in the corporate sector in Chile, analyzes the current state of the foreign exchange derivatives market in Chile, and argues that liquid and developed foreign exchange derivatives markets can help promote financial stability.

JEL Classification Numbers: G1, G10, G15

Keywords: Chile, derivatives market, forward contracts, currency options

Author(s) E-Mail Address: jchanlau@imf.org

\footnotetext{
${ }^{1}$ This paper benefitted from comments by Vittorio Corbo, Marco Espinosa-Vega, Christopher Faulkner-McDonough, Herve Ferhani, Rodolfo Luzio, David Ordoobadi, Jorge Selaive, Gilbert Terrier, Christopher Towe, and participants in a seminar organized by the Central Bank of Chile. Errors and omissions remain the author's sole responsibility.
} 


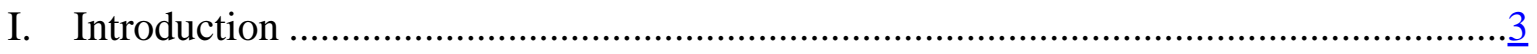

II. Foreign Exchange Exposure in Chile ..................................................................

III. The Market of Foreign Exchange Derivatives ....................................................

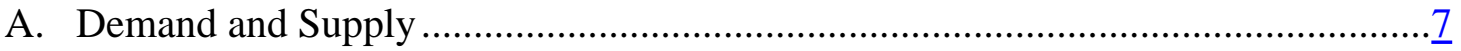

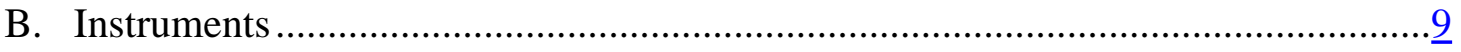

IV. Fostering the Growth of the Foreign Exchange Derivatives Market.......................... 16

V. Foreign Exchange Hedging and Financial Crises ........................................... 17

VI. Conclusions..........................................................................................

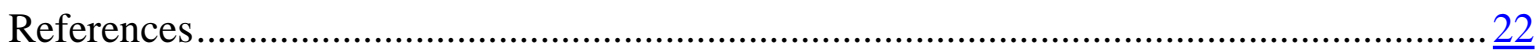

Tables

1. Firm and industry level exposure, Chile and other countries ..................................

2. Chile: Foreign exchange risk exposure ................................................................

3. Pension fund foreign assets and potential supply of foreign exchange

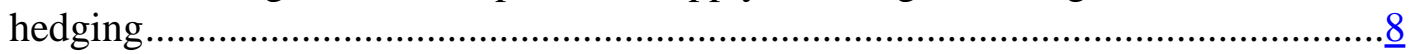

4. Maturity breakdown of onshore forward contracts........................................ $\frac{10}{12}$

5. Opportunity cost of hedging with 3-month forward contracts.................................12

6. Offshore over-the-counter currency options: implied volatilities............................. 13

7. Offshore option premium........................................................................... 16

Figures

1. 3-month forwardrates and subsequent spot rate.................................................. 11

2. Implied volatilities of offshore, over-the-counter currency options .......................... 14

3. Offshore option premium: Chile, Australia, and New Zealand -U.S. dollar calls ........ $\underline{15}$

Boxes

1. Assessing Foreign Exchange Exposure using Factor Analysis ................................. 19

2. What Factors Determine the Deamnd for Foreign Exchange Hedging .......................20

3. How Currency Derivatives Can Contribute to Destabilize Exchange Rates During Periods of Distress .................................................................................. 


\section{INTRODUCTION}

A market for foreign exchange hedging instruments can help domestic corporations to manage currency mismatches between assets and liabilities. In the absence of markets for foreign exchange hedging, currency mismatches can be hedged if governments accumulate large foreign reserves. Accumulating reserves, though, may have substantial opportunity costs. ${ }^{2}$ In addition, if a country accumulates reserves to "bail out" private institutions in case of adverse exchange rate movements, the country is essentially subsidizing foreign exchange hedging at the expense of depressed investment and consumption. Arguably, then, the provision of foreign exchange hedging will be better undertaken if done by the private sector rather than by the government.

This paper explores the following questions about the market for foreign exchange hedging in Chile: (i) the foreign exchange exposure of the Chilean corporate sector; (ii) the determinants of the demand and supply of foreign exchange hedging; (iii) the instruments available for hedging foreign exchange risk; (iii) the impact of the regulatory framework and market structure on the growth of the foreign exchange derivatives market; and finally, (iv) the degree to which foreign exchange risk hedging reduces systemic vulnerabilities to financial crises.

\section{Foreign EXCHANGE EXPOSURE IN CHILE}

In Chile, systemic risk from currency mismatches in corporate balance-sheets appears to be low, as foreign exchange exposure in Chile is low compared to other developed and emerging market countries. Caballero, Kowan, and Kearns (2004) report that the mean and median share of foreign currency liabilities in Chile are approximately 28 percent and 5 percent, compared to more than 50 percent and 60 percent respectively, in Argentina, Peru, and Uruguay. These authors also note that foreign exchange liabilities appear to be concentrated mainly in the tradable sector, a sector that may be able to withstand adverse exchange rate movements better than other industrial sectors. Central Bank figures also indicate that 84 percent of the total external debt in the non-financial private sector, standing at $\$ 24.9$ billion or 34 percent of GDP by end-2003, is tilted towards medium and long-term maturities. The relatively long maturity profile reduces corporate sector vulnerabilities to adverse exchange rate movements. Finally, findings by Dominguez and Tesar (2001) suggest that foreign exchange exposure is significant only for 13 percent of publicly listed firms. At the industry level, the exposure only affects 17 percent of all industries. Foreign exchange exposure in the Chilean corporate sector is thus significantly lower than in other countries (Table 1).

\footnotetext{
${ }^{2}$ For instance, Edison (2003) estimates that it costs 1 percent of GDP to increase reserves by 10 percent of GDP.
} 
Table 1. Firm and industry level exposure, Chile and other countries

\begin{tabular}{lcc} 
& $\begin{array}{c}\text { Firm level exposure, } \\
\text { in percent }\end{array}$ & $\begin{array}{c}\text { Industry level exposure, } \\
\text { in percent }\end{array}$ \\
\hline Chile & 13.6 & 17.4 \\
France & 18.9 & 17.1 \\
Germany & 20.6 & 64.7 \\
Italy & 26.3 & 32.3 \\
Japan & 31.1 & 59.5 \\
Netherlands & 26.3 & 40.0 \\
Thailand & 21.3 & 25.0 \\
United Kingdom & 18.8 & 46.2 \\
& & \\
\hline
\end{tabular}

Source: Dominguez and Tesar (2001).

Factor analysis suggests the financial sector has been the most exposed to foreign exchange risk. $^{3}$ Table 2 shows the sensitivity of equity returns in different industrial sectors to exchange rate changes after controlling for movements in the overall stock market. A higher coefficient associated to the exchange rate changes indicates higher exposure. Clearly, the financial sector has been the most exposed before and after the abandonment of the floating band in September 1999. Interestingly, the exposure has increased although data compiled by the Financial Sector Assessment Program (FSAP) suggests that banks in Chile hedge between 90 to 100 percent of their net foreign exchange positions (Mendelson and Glaessner, 2004). Foreign exchange hedging, however, does not imply that banks' equity returns should be insensitive to exchange rate movements. For instance, exchange rate movements may have an impact on interest rates, and hence, affect the profitability of the floating rate loan portfolio.

Banks, however, appear resilient to market risk arising from adverse exchange rate movements. A recent FSAP mission to Chile concluded that solvency ratios in the banking system would not be seriously affected in the event of devaluation, even if combined with increases in interest rates and deteriorating credit quality in their loan portfolios (Gutierrez, 2004).

${ }^{3}$ See Box 1 for a detailed explanation of the empirical method and the data used in the analysis. 
Table 2. Chile: Foreign exchange risk exposure

\begin{tabular}{|c|c|c|c|c|}
\hline & $\begin{array}{c}\text { Consumer } \\
\text { Discretionary } \\
\end{array}$ & $\begin{array}{c}\text { Consumer } \\
\text { Staples } \\
\end{array}$ & Financials & Health Care \\
\hline & \multicolumn{4}{|c|}{ Sample period: January 1995 - December 1999} \\
\hline \multirow[t]{2}{*}{ Constant } & -2.367 & 0.495 & 0.907 & 0.194 \\
\hline & -1.291 & 0.608 & 0.717 & 0.152 \\
\hline \multirow[t]{2}{*}{ Exchange rates } & 0.289 & 0.105 & 0.286 & 0.054 \\
\hline & 2.345 & 1.804 & 3.229 & 0.570 \\
\hline \multirow[t]{2}{*}{ Total stock market } & 0.596 & 0.672 & 0.657 & 0.808 \\
\hline & 15.392 & 36.709 & 23.502 & 27.107 \\
\hline Adjusted R-squared & 0.959 & 0.973 & 0.959 & 0.965 \\
\hline F-statistic & 9820 & 15331 & 9884 & 11653 \\
\hline \multirow[t]{2}{*}{ Durbin-Watson statistic } & 2.056 & 1.854 & 1.813 & 1.974 \\
\hline & \multicolumn{4}{|c|}{ Sample period: January 1995 - December 1999} \\
\hline \multirow[t]{2}{*}{ Constant } & 1.355 & -0.144 & 0.858 & 2.111 \\
\hline & 0.919 & -0.128 & 0.715 & 1.577 \\
\hline \multirow[t]{2}{*}{ Exchange rates } & -0.195 & 0.174 & 0.387 & 2.020 \\
\hline & -1.611 & 2.186 & 4.169 & -0.586 \\
\hline \multirow[t]{2}{*}{ Total stock market } & 0.998 & 0.879 & 0.537 & 0.853 \\
\hline & 25.044 & 33.549 & 17.429 & 21.961 \\
\hline Adjusted R-squared & 0.974 & 0.985 & 0.966 & 0.966 \\
\hline F-statistic & 14234 & 24400 & 10541 & 10549 \\
\hline \multirow[t]{2}{*}{ Durbin-Watson statistic } & 1.891 & 1.821 & 1.939 & 2.020 \\
\hline & \multicolumn{4}{|c|}{ Sample period: January 1995 - April 2004} \\
\hline \multirow[t]{2}{*}{ Constant } & -0.490 & 0.276 & 0.849 & 1.090 \\
\hline & -0.387 & 0.368 & 0.989 & 1.163 \\
\hline \multirow[t]{2}{*}{ Exchange rates } & 0.008 & 0.124 & 0.349 & -0.016 \\
\hline & 0.091 & 2.508 & 5.447 & -0.212 \\
\hline \multirow[t]{2}{*}{ Total stock market } & 0.802 & 0.775 & 0.595 & 0.832 \\
\hline & 28.525 & 48.577 & 28.638 & 34.213 \\
\hline Adjusted R-squared & 0.969 & 0.982 & 0.963 & 0.966 \\
\hline F-statistic & 24856 & 43409 & 20756 & 22939 \\
\hline Durbin-Watson statistic & 1.980 & 1.802 & 1.879 & 2.009 \\
\hline
\end{tabular}

Sources: Morgan Stanley Capital Indices and staff calculations. Bold fonts indicate coefficient is statistically significant at the 10 percent level at least; t-statistics in italics. 
Table 2 (cont.). Chile: Foreign exchange risk exposure

\begin{tabular}{|c|c|c|c|c|}
\hline & Industrials & Materials & Telecommunications & Utilities \\
\hline & \multicolumn{4}{|c|}{ Sample period: January 1995 - December 1999} \\
\hline \multirow[t]{2}{*}{ Constant } & -0.601 & -1.171 & 1.528 & -0.061 \\
\hline & -0.494 & -1.490 & 1.287 & -0.140 \\
\hline \multirow[t]{2}{*}{ Exchange rates } & 0.133 & -0.037 & -0.210 & 0.006 \\
\hline & 1.701 & -0.733 & -2.808 & 0.177 \\
\hline \multirow[t]{2}{*}{ Total stock market } & 0.210 & 0.814 & 1.145 & 1.175 \\
\hline & 8.538 & 51.484 & 48.899 & 117.898 \\
\hline Adjusted R-squared & 0.953 & 0.987 & 0.981 & 0.995 \\
\hline F-statistic & 8637 & 32047 & 21568 & 89824 \\
\hline \multirow[t]{2}{*}{ Durbin-Watson statistic } & 1.761 & 2.006 & 1.624 & 1.816 \\
\hline & \multicolumn{4}{|c|}{ Sample period: January 1995 - December 1999} \\
\hline \multirow[t]{2}{*}{ Constant } & 2.634 & 0.724 & -0.710 & -0.057 \\
\hline & 0.801 & 0.496 & -0.413 & -0.059 \\
\hline \multirow[t]{2}{*}{ Exchange rates } & 0.018 & 0.066 & -0.136 & -0.149 \\
\hline & 0.078 & 1.044 & -1.427 & -2.836 \\
\hline \multirow[t]{2}{*}{ Total stock market } & 0.090 & 0.763 & 1.356 & 1.124 \\
\hline & 1.144 & 36.389 & 43.098 & 64.955 \\
\hline Adjusted R-squared & 0.933 & 0.988 & 0.982 & 0.990 \\
\hline F-statistic & 5201 & 30580 & 20087 & 37319 \\
\hline \multirow[t]{2}{*}{ Durbin-Watson statistic } & 1.936 & 1.800 & 1.630 & 1.784 \\
\hline & \multicolumn{4}{|c|}{ Sample period: January 1995 - April 2004} \\
\hline \multirow[t]{2}{*}{ Constant } & 0.868 & -0.321 & 0.564 & -0.107 \\
\hline & 0.510 & -0.398 & 0.555 & -0.204 \\
\hline \multirow[t]{2}{*}{ Exchange rates } & 0.083 & 0.023 & -0.190 & -0.072 \\
\hline & 0.661 & 0.564 & -3.127 & -2.348 \\
\hline \multirow[t]{2}{*}{ Total stock market } & 0.151 & 0.787 & 1.251 & 1.151 \\
\hline & 3.763 & 60.491 & 63.990 & 116.809 \\
\hline Adjusted R-squared & 0.937 & 0.988 & 0.981 & 0.99241 \\
\hline F-statistic & 11856 & 65183 & 41472 & 104517 \\
\hline Durbin-Watson statistic & 1.923 & 1.877 & 1.626 & 1.776844 \\
\hline
\end{tabular}

Sources: Morgan Stanley Capital Indices and staff calculations. Bold fonts indicate coefficient is statistically significant at the 10 percent level at least; t-statistics in italics. 


\section{The MARKet OF Foreign EXchANGE DERIVATIVES}

\section{A. Demand and Supply}

Foreign exchange derivatives in Chile are traded mainly in the over-the-counter market, and banks have a major role as market makers. ${ }^{4}$ Domestic banks and financial institutions can write a variety of derivatives instruments, and are responsible for matching corporate endusers and institutional investors' needs to cover exchange rate risk. ${ }^{5}$ Commercial banks are allowed to take positions on foreign futures contracts on foreign currency and interest rates, and on exchange-traded options on foreign currency and interest rate futures. Thus, commercial banks that act as market makers in the local market can hedge their net positions offshore if needed.

Demand for foreign exchange hedging comes mainly from large corporations, mostly because they have the resources and skills to implement foreign exchange hedging programs. In consequence, they participate actively in the foreign exchange derivatives market. Small and medium enterprises, however, seldom hedge their foreign exchange exposures because of lack of knowledge about the benefits of hedging using financial instruments. Currently, local banks are organizing seminars to educate end-users in the small and medium enterprise sector about the benefits of foreign exchange hedging. Some market analysts also suggest that foreign exchange hedging may not be used more widely even among large corporations because it requires sacrificing the option to prepay dollar liabilities.

Financial institutions hedge a higher share of their currency exposure than non-financial institutions. In Chile, banks hedge 90 to 100 percent of their exposure, while corporations hedge only 40 percent (IMF and World Bank, 2004). This is not surprising since the exposure of financial institutions is associated mostly to transactions on nominal contracts and a limited number of risk factors, which are easy to measure. Also, staff in financial institutions is more familiar with risk management techniques. In contrast, the exposure of non-financial corporations is difficult to assess since their exposure is not only related to financial assets and liabilities, but also to operating decisions.

Empirical evidence from small industrialized countries suggests that financial distress can often be the main driver of foreign exchange hedging in the corporate sector. The demand for

\footnotetext{
${ }^{4}$ The regulation of foreign exchange derivatives in Chile follows the guidelines contained in the Law of Banks and Financial Institutions, and in the Law of Capital Markets. In addition, these contracts must satisfy the Central Bank regulations related to exchange rate markets and financial institutions.

${ }^{5}$ These instruments include futures, forwards, swaps, and combinations of these instruments on the domestic currency, inflation-linked indexes, interest rates, and foreign currency and interest rates. See Fernandez (2001) for a comprehensive analysis and description.
} 
hedging is determined mainly by three factors: the costs of financial distress, tax advantages, and agency costs among different stakeholders in the firm (Box 2). Empirical studies in small industrialized countries using survey data suggest financial distress is the main determinant of hedging. Jalilvand (1999) found that proxies for the costs of financial distress explain why Canadian firms use derivatives. For instance, firms with higher leverage and lower credit rating tend to use more derivatives. Taxes and agency costs were not important for Canadian firms. Financial distress also explains derivative usage in Australia, as found by Nguyen and Faff (2002). Finnish and Swedish firms also use currency derivatives to reduce financial distress costs, according to Hakkrainen et al (1998), and Hagelin (2003) respectively. Arguably, financial distress may also be the main determinant of hedging in Chile, an hypothesis that may be testable using FECUS data.

Pension funds are the main providers of foreign exchange hedging to corporate end-users. As of end-December 2003, pension funds held 24 percent of their assets, or \$11.9 billion, in foreign assets, most of them denominated in U.S. dollars (Table 3). Minimum coverage requirements of foreign assets makes pension funds the natural providers of foreign currency hedging to corporate end-users since they have an incentive to take the foreign currency paying leg of a derivatives transaction. Furthermore, the sizable foreign asset holdings of pension funds (14 percent of GDP) implies there is no shortage of foreign exchange hedging to meet corporate end users' needs. Indeed, by end-December 2003, institutional investors had an outstanding dollar-paying position of $\$ 7.7$ billion compared to the outstanding dollarbuying position of \$ 2.9 billion of corporations (Alarcón, Selaive, and Villena, 2004).

Table 3. Pension fund foreign assets and their potential supply of foreign exchange hedging

\begin{tabular}{lccc}
\hline Type of Fund 1/ & $\begin{array}{c}\text { Foreign assets, } \\
\text { in millions USD }\end{array}$ & $\begin{array}{c}\text { Minimum foreign } \\
\text { exchange coverage, } \\
\text { in percent }\end{array}$ & $\begin{array}{c}\text { Minimum potential supply of } \\
\text { foreign exchange hedging, } \\
\text { in millions USD }\end{array}$ \\
\hline A & 1318 & 63 & 831 \\
B & 2739 & 78 & 2136 \\
C & 172 & 82 & 141 \\
D & 6437 & 87 & 5600 \\
E & 1202 & 91 & 1094 \\
& 11867 & & 9801
\end{tabular}

\footnotetext{
Sources: Asociacion AFP and staff calculations.

$1 /$ The maximum and minimum equity investment limits as percent of assets under management for Type A funds are 80 and 40 percent, for Type B funds, 60 and 25 percent, for type C funds, 40 and 15 percent, and for type D funds, 20 and 5 percent. Type E funds are not allowed to invest in equities.
}

Exporters are also important providers of foreign exchange hedging to corporate end-users. According to market analysts and discussions with corporate treasurers, exporters also take foreign currency-paying positions in derivatives contracts. Central bank data show that 
foreign-currency paying positions of corporate end-users, mainly exporters, amounted to \$ 4.8 billion or close to 28 percent of the total amount of foreign-currency paying positions in the domestic derivatives market in 2003 (Alarcón, Selaive, and Villena, 2004). However, some big exporters such as Codelco, prefer to conduct transactions in the spot market rather than the forward market because earnings volatility is not considered a major concern for their financial operations.

The supply of foreign exchange hedging, however, is concentrated on derivatives contracts with short maturities. Pension funds and exporters take foreign currency paying positions in derivatives contracts with maturities of three months or less, according to market analysts. Furthermore, analysts also note that pension fund managers do not always cover their long foreign currency positions fully since carrying naked dollar positions during periods of dollar appreciation is profitable.

Banks, therefore, are the suppliers of foreign exchange hedging for maturities of one year and above. Banks hedge the foreign exchange exposure arising from these long-term forward contracts with dollar and dollar-linked bonds issued by the Central Bank. Market analysts estimate that the outstanding amount of forward contracts with maturities above one year exceeds banks' holdings of dollar and dollar linked instruments by 50 percent, implying that banks carry an unhedged position in Chilean pesos. Banks' exposure, though, is rather small given that these contracts only account for 1 percent of the forward market, as explained in the next section. ${ }^{6}$

\section{B. Instruments}

\section{Forward Contracts}

Forward contracts can be traded either onshore or offshore. In the onshore market, contracts can be written for Chilean pesos and Unidades de Fomento against the U.S. dollar, though the former are preferred. Nine out of ten contracts are non-deliverable (Moguillansky, 2002). In the offshore market, forward contracts are non-deliverable and written only for Chilean pesos. Market analysts indicate that domestic corporations find more advantageous to hedge their exposure in the onshore market while the offshore market is used mainly by leveraged foreign investors. The average daily volume for the past three years have been in the range of

\footnotetext{
${ }^{6}$ Back of the envelope calculations using figures reported by Alarcón, Selaive, and Villena (2004) and the opportunity costs detailed below suggest that the banks' exposure arising from unhedged long-maturity forward contracts amounts only to \$50-60 million, or barely 0.1 percent of total assets in the financial system.
} 
\$100 million dollars, according to market analysts, to \$ 600 million, according to Central bank data. The average face value of a forward contract is $\$ 5$ million. $^{7}$

The maturity breakdown of forward contracts in the onshore market is similar to that observed in Australia and New Zealand. In Chile, 21 percent of contracts are conducted for maturities of one week and less, 78 percent for maturities between 7 days and one year, and 1 percent for maturities of one year and above. The corresponding figures for Australia are 61 percent, 31 percent, and 8 percent, and for New Zealand, 41 percent, 58 percent, and 1 percent (Table 4). Because a majority of contracts have very short maturities, hedging in the forward market may not contribute much to reduce cash flow volatility. This situation, however, is similar to the one in Australia and New Zealand (Figure 1).

Table 4. Maturity breakdown of onshore forward contracts

Forward contract maturities

\begin{tabular}{lccc}
\hline & 1 week or less & $\begin{array}{c}\text { Over 1 week and } \\
\text { less than 1 year }\end{array}$ & Over 1 year \\
\hline Chile & 21 & 78 & 1 \\
Australia & 61 & 31 & 8 \\
New Zealand & 41 & 58 & 1 \\
\hline
\end{tabular}

Source: BIS (2002)

The onshore forward market is quite liquid for contracts with maturities of three months or less. Market participants indicate that the forward market for contracts with maturities of one year or less is a two-way market: the demand for foreign currency hedging by corporations with short dollar positions is mostly met by the supply of hedging from institutions with long dollar positions such as exporters and pension funds.

The cost of using forwards, as measured by the bid-ask spread as a percent of the forward rate, is low compared to emerging market countries. In Chile, the bid-ask spread is 8 basis points for one-month contracts. Compared to emerging market countries, the bid-ask spread in Chile is half of that observed in Brazil (15 basis points), similar to the spread in South Korea (8 basis points), but still higher than in small industrialized countries like New Zealand (4 basis points) and Australia (2 basis points) (Mendelson and Glaessner, 2004, and Alarcon, Selaive, and Villena, 2004).

\footnotetext{
${ }^{7}$ Anidjar (2002), Estrategia (Feb. 16, 2004), and Romo, Castro, and Abdel-Mootal (2002). Central bank figures indicate a higher daily turnover of \$625 million in 2001 (Bank for International Settlements, 2001).
} 
Figure 1. 3-months forward rates and subsequent spot rate
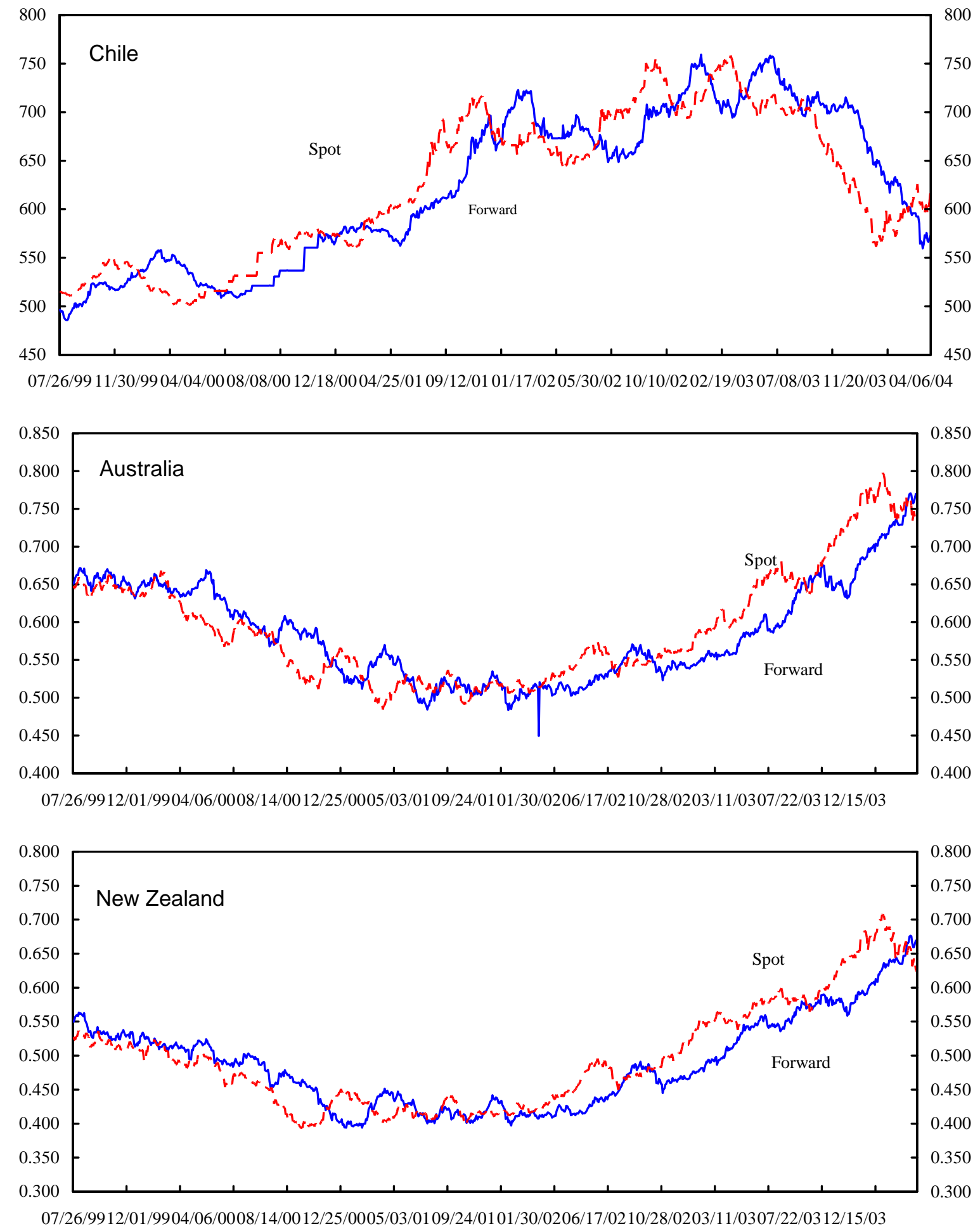

Source: JPMorgan Chase. 
The opportunity cost of hedging with forward contracts is comparable to costs in Australia and New Zealand. The opportunity cost can be measured as the foreign exchange gains foregone by locking in the exchange rate in advance. The higher the opportunity cost, the lower the incentives to hedge foreign exchange risk. Opportunity costs in Chile, measured as the difference in percent between the realized spot rate at the time the contract matures and the forward rate at the inception of the contract, are slightly lower than in Australia and New Zealand (Table 5). For the period April 2001 to April 2004, the average opportunity cost in Chile was similar to that in Australia and lower than in New Zealand. With respect to the maximum gain foregone by entering a forward contract, Chile also fared better than the other two countries during the time period examined.

Table 5. Opportunity cost of hedging with 3-month forward contracts (measured as percent of forward rate at inception)

\begin{tabular}{lccc}
\hline & CLP & AUD & NZD \\
\hline Average & 4.68 & 4.76 & 5.69 \\
Maximum & 13.20 & 16.11 & 15.99 \\
Minimum & 0.00 & 0.00 & 0.01 \\
Volatility & 2.90 & 3.78 & 4.11 \\
& & & \\
\hline
\end{tabular}

Source: JPMorgan Chase and staff calculations

Forward contracts in Chile, though, have additional costs that can work against their widespread use by corporate end-users. Corporate end-users that enter a forward contract with a bank may be required to post collateral with the bank because of counterparty risk. On average, the collateral requirement is equal to 5 percent of the nominal value of the contract for maturities less than 30 days, 7 percent to 10 percent for maturities over 30 days and up to 180 days, and 15 percent for maturities over 180 days and up to 360 days (Diario Estrategia, 2004). Even if corporations meet the credit ratings requirements of the bank underwriting the forward contract, the approval of a credit line is required. The credit line is costly since it ties up the bank's economic capital. The cost of the credit line is passed on to the end-user as less favorable forward rates.

These additional costs, that are tied up to the credit rating of the corporate end-user, may contribute to the observed low hedge ratios in the corporate sector. The collateral requirement and the use of credit lines may explain why only 40 percent of foreign exchange liabilities were hedged using forwards (Mendelson and Glaessner, 2004), a figure well below those observed in other small industrialized countries. For example, results from a special survey in 1999 showed that in New Zealand financial contracts were used to hedge 64 percent of foreign currency denominated liabilities. 


\section{Currency Options}

Plain vanilla currency options on U.S. dollar-Chilean peso (USD-CLP) are available offshore at prices similar to those quoted for U.S. dollar-Australian dollar (USD-AUD) and U.S. dollar-New Zealand dollar (USD-NZD) options. A simple way to measure the costs of using currency options for hedging is to use the implied volatility of at-the-money forward contracts. $^{8}$ Table 6 indicates similar average implied volatility for USD-CLP, USD-AUD, and USD-NZD options during the period September 2000-April 2004 (see also Figure 2). While there are no figures about volumes traded in the offshore market, liquidity is less for USD-CLP options than for USD-AUD and USD-NZD options, as shown by less frequent changes in implied volatilities for the former currency option (Figure 2). Furthermore, USDAUD options were the seventh most traded currency option contracts in the world, with a daily average traded volume of $\$ 40$ billion in outstanding notional amount in 2001 (BIS, 2002).

Table 6. Offshore over-the-counter currency options: implied volatilities

\begin{tabular}{lccccccccc}
\hline & \multicolumn{3}{c}{ 1-month contract } & \multicolumn{3}{c}{ 3-month contract } & \multicolumn{3}{c}{ 12-month contract } \\
& CLP & AUD & NZD & CLP & AUD & NZD & CLP & AUD & NZD \\
\hline & & & & & & & & & \\
Average & 10.67 & 11.45 & 12.65 & 10.67 & 11.45 & 12.65 & 12.00 & 11.21 & 12.44 \\
Maximum & 17.33 & 17.34 & 19.11 & 17.33 & 17.34 & 19.11 & 18.17 & 13.91 & 15.83 \\
Minimum & 6.00 & 7.09 & 8.45 & 6.00 & 7.09 & 8.45 & 9.00 & 9.43 & 10.10 \\
Standard Deviation & 2.23 & 2.22 & 2.41 & 2.23 & 2.22 & 2.41 & 1.60 & 1.19 & 1.48 \\
& & & & & & & & & \\
\hline
\end{tabular}

Source: JP Morgan Chase and staff calculations.

While implied volatility can be used as a first approximation of an option premium, it may also reflect the compensation investors demand for expected realized volatility. Hence, high implied volatilities may reflect higher expected realized volatility and viceversa. The option premium, thus, is a better indicator of the option costs. Figure 3 shows the option premium for USD-CLP, USD-AUD, and USD-NZD options for the period May 2003-April 2004. The premium is lower for the Australian dollar, especially for the 6-month maturity contract, arguably reflecting higher liquidity in this market. The cost of hedging U.S. dollars using offshore currency options is similar for Chile and New Zealand. Table 7 summarizes the descriptive statistics of the U.S. call contracts for each currency. While there are not substantial price differences across currencies, the volatility of the USD-CLP option

${ }^{8}$ Pricing convention in the over-the-counter market specifies the price of an option in terms of volatility, which must be replaced in the Garman-Kolhagen (1983) formula to obtain the option premium. At-the-money forward option contracts specify the forward rate at the maturity date as the strike price. 
premium is twice as high as the premium volatilty of Australian and New Zealand dollar options.

Figure 2. Implied volatilities of offshore, over-the-counter currency options
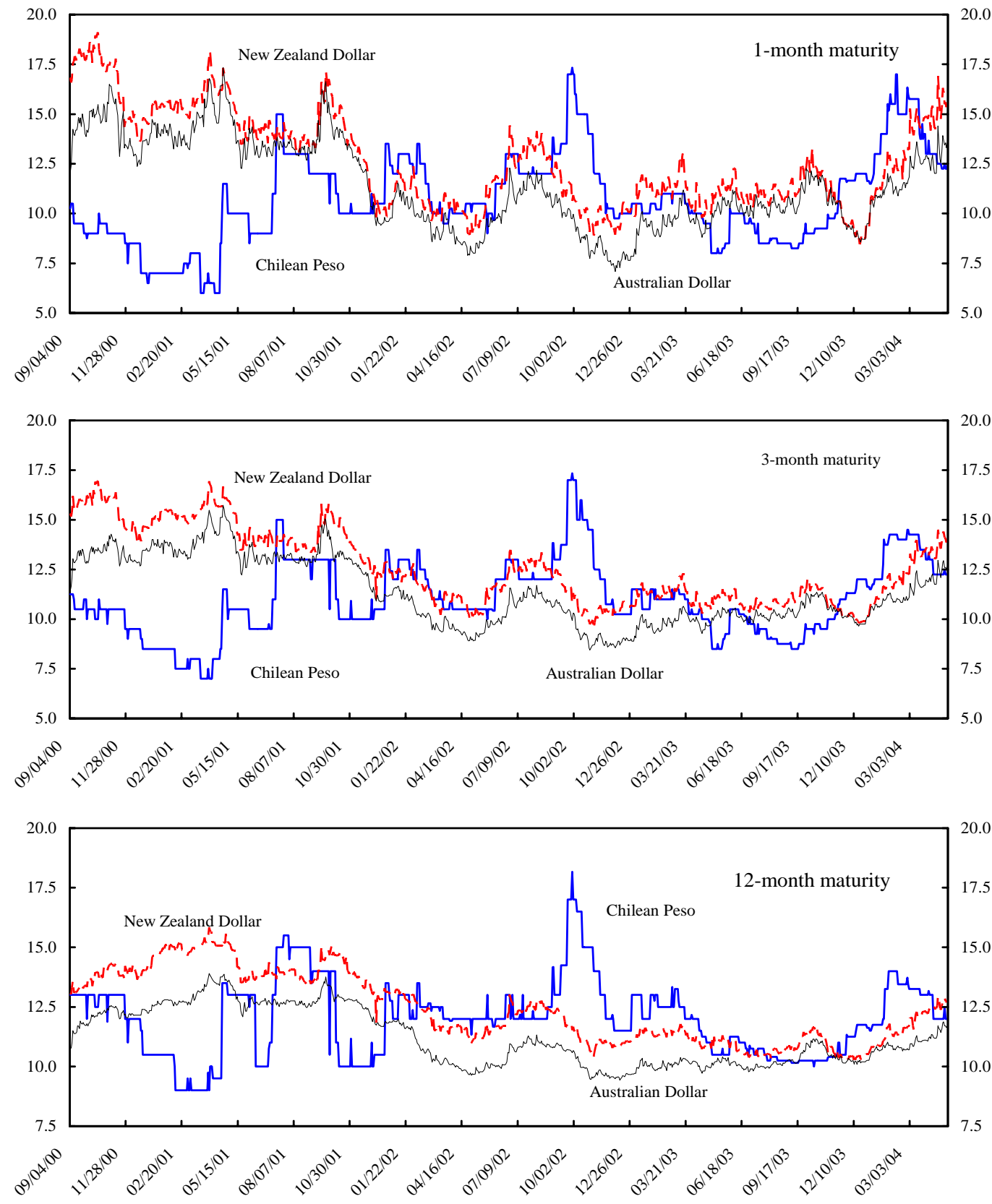

Source: JPMorgan Chase. 
Figure 3. Offshore Option Premium: Chile, Australia, and New Zealand -U.S. dollar calls (in percent of spot rate)
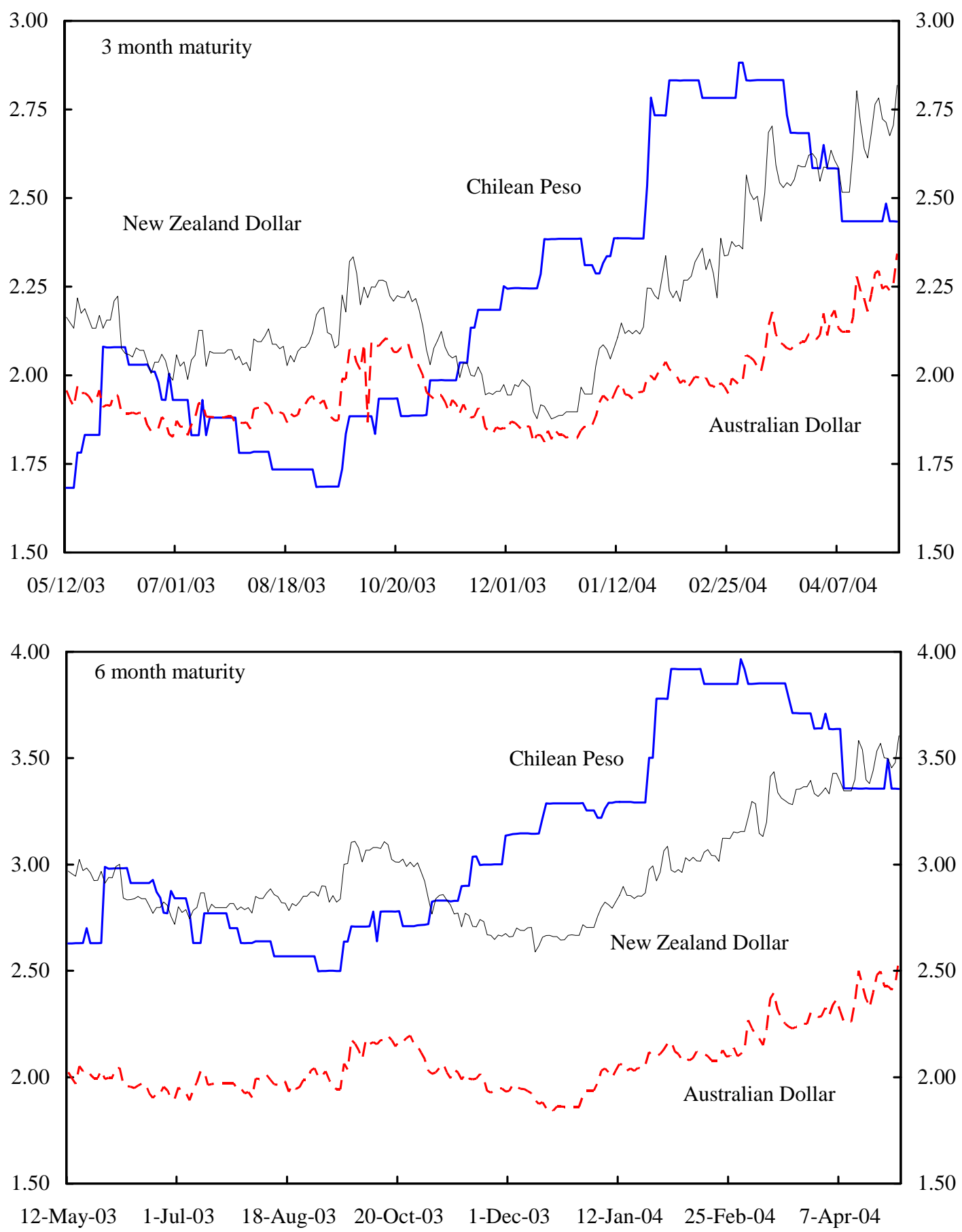

Source: JPMorgan Chase and staff calculations. 
Table 7. Offshore option premium, in percent of spot rate

\begin{tabular}{lcccccr} 
& \multicolumn{3}{c}{ 3 month maturity } & & 6 month maturity \\
& $\begin{array}{c}\text { Chilean } \\
\text { Peso }\end{array}$ & $\begin{array}{c}\text { Australian } \\
\text { Dollar }\end{array}$ & $\begin{array}{c}\text { New Zealand } \\
\text { Dollar }\end{array}$ & $\begin{array}{c}\text { Chilean } \\
\text { Peso }\end{array}$ & $\begin{array}{c}\text { Australian } \\
\text { Dollar }\end{array}$ & $\begin{array}{c}\text { New Zealand } \\
\text { Dollar }\end{array}$ \\
\hline & & & & & & \\
Average & 2.20 & 1.98 & 2.22 & 3.11 & 2.08 & 2.98 \\
Maximum & 2.88 & 2.42 & 2.89 & 3.97 & 2.68 & 3.67 \\
Minimum & 1.68 & 1.81 & 1.88 & 2.50 & 1.84 & 2.59 \\
Volatility & 0.38 & 0.13 & 0.24 & 0.45 & 0.17 & 0.25 \\
& & & & & & \\
\hline
\end{tabular}

Source: JPMorgan Chase and staff calculations.

There is an incipient onshore, over-the-counter currency options market whose growth has been constrained by regulation. Regulation prevents banks from offering option contracts. In order to circumvent this constraint, banks have set up affiliates or "sociedades de inversion" to offer these contracts to corporations. Corporate demand for these contracts remain low for two reasons, according to market analysts. First, in contrast to a forward contract, the option premium has to be paid upfront. Corporate users viewed this payment as a cost rather than the price of insuring against adverse exchange rate movements. Second, there is the perception that currency options may be "illegal" contracts since banks cannot offer them directly to their clients. As a result, the option market is very thin with a daily average volume of \$2.5 million. The customer base in this market is comprised by large corporations.

Reflecting these regulatory constraings, currency options in the onshore market are rather expensive compared to offshore options. Option premia in the onshore over-the-counter market are quoted as a percentage of the spot rate, and currently, it stands at 3 percent for the three-month contract, and 4 percent for the 6 month contract (Diario Estrategia, Feb. 16, 2004). Compared to offshore options, domestic currency options are expensive since the average premium during the period April 2003-2004 was 2.2 percent for the 3-month contract, and 3.11 percent for the six-month contract (Figure 3).

\section{FOSTERING THE GROWTH OF THE FOREIGN EXCHANGE DERIVATIVES MARKETS}

The growth of the foreign exchange derivatives market can enhance risk allocation during normal times. More efficient risk transfer, better investment decisions, and lower exchange rate volatility justify adopting policy measures that foster growth of the currency derivatives market. In addition, derivatives markets may help reduce agency problems that affect investment decisions by firms. Thus, increased availability of currency derivatives could contribute to enhance a country's welfare. While there are no specific studies on how introducing currency derivatives affects existing markets, empirical studies also suggest that the volatility of the underlying asset declines substantially following the introduction of options (Conrad, 1989; Detemple and Jorion, 1990). 
The development of the derivatives market, including foreign exchange contracts, requires modernizing current clearing and settlement systems and continuing the implementation of market friendly policies. ${ }^{9}$ There are still some legal and operational voids affecting the clearing and settlement systems, especially those related to the netting of positions. Among market friendly policies, authorities may consider removing restrictions on derivatives trading for pension funds and insurance companies. In addition, authorities may want to consider fostering the development of derivatives exchanges as a complement to the overthe-counter market. Exchanges do a better job than over-the-counter markets in decentralizing risk, reducing counterparty risk and its associated costs, facilitating price discovery, and allowing access to risk sharing instruments to small corporations.

\section{Foreign EXChange Hedging ANd FinANCial Crises}

During periods of extreme financial distress, however, the availability of currency derivatives may exacerbate systemic risk in a country's financial system. Prior to the occurrence of a financial crisis, markets become one-sided as firms and investors look forward to hedge their foreign currency exposures, using short-term instruments. With few or no investors willing to step in on the other side of the trade, market makers are forced to hedge their exposure by short-selling the domestic currency on the spot market. As a result, the domestic currency weakens further, domestic interest rates rise, volatility increases and corporate solvency deteriorates. A vicious circle emerges as continued weakening of the domestic currency prompts further demand for foreign currency hedge. ${ }^{10}$

In addition, a liquid domestic derivatives market may also contribute to the transmission of financial crisis from neighboring countries. For instance, it has been reported that volatility in the Chilean foreign exchange market increased during the second half of 2001 in the run-up to the Argentinean sovereign default. The surge in volatility has been attributed to multinational firms' decision to hedge their currency exposures on Argentinean pesos using currency derivatives traded in the local Chilean market (Moguillansky, 2002).

Systemic risk arising from derivatives transactions may be reduced through derivatives exchanges and centralized clearing-houses. When derivatives trading is concentrated among a handful of market makers, as is the case in Chile, the failure of one market maker can trigger a chain reaction. A centralized clearing-house reduces this risk by acting as the sole counterparty to all the exchange members. Risk is also reduced as the clearing-house nets aggregate positions across members. Furthermore, it is easier for authorities to monitor and regulate activities in the derivatives market if all information is concentrated on the clearinghouse (Steinherr, 2000).

\footnotetext{
${ }^{9}$ IMF (2002), and IMF and World Bank (2004).

${ }^{10}$ See Box 3 for a detailed description of price dynamics arising from hedging forward and currency option positions.
} 


\section{ConClusions}

Foreign exchange exposure in Chile is lower than in other countries in the region, and similar to that observed in small industrialized countries. The most exposed sector is the financial sector. However, this is not a major source of systemic risk since a recent assessment of financial sector in Chile suggests that banks can withstand severe exchange and interest rate shocks successfully.

Managing currency exchange risk has been facilitated by a well-functioning forward market. There exists a two-way market, with pension funds and exporters taking foreign-currency paying positions and domestic corporate end-users taking foreign-currency buying positions. Currently, the foreign exchange hedging needs of domestic users are met fully by pension funds and exporters. This situation is likely to continue as the pension fund industry continues to grow. Liquidity in the forward market, as measured by bid-ask spreads, is lower than in most emerging markets and deemed satisfactory by market participants.

Counterparty credit risk and lack of sophistication prevent small and medium enterprises from accessing the forward market. Banks require collateral from clients who do not meet internal credit rating requirements. Also, underwriting a forward contract requires first extending a credit line to the end-user. Costs associated to collateral and credit lines are passed on to the end-user as less favorable forward rates. Finally, corporate treasurers in the SME sector lack the needed training to manage currency risk actively.

Growth in the currency options market has been constrained by regulation. Allowing banks and pension funds to underwrite currency options could help fostering the development of this market. Currency options are valuable tools for hedging foreign exchange risk since their non-linear payoffs cannot be replicated with forward contracts. Also, establishing a liquid market of plain-vanilla currency options is a necessary step to introduce more exotic options.

Notwithstanding the benefits associated with currency derivatives markets, these markets may be a source of instability during periods of financial turmoil. In the absence of derivatives markets, speculative attacks are channeled through spot markets. Hence, the central bank can defend the exchange rate by intervening directly in the spot market. When derivatives markets exist, speculators can take virtually unlimited positions in forward and swap markets and reduce the effectiveness of Central bank's intervention (Dodd, 2001). Furthermore, as markets become one-sided, dynamic hedging in the derivatives market can amplify market movements. Authorities should bear these risks in mind while fostering the development of the derivatives market. 


\section{Box 1. Assessing Foreign Exchange Exposure using Factor Analysis}

The foreign exchange exposure of a particular firm or industrial sector can be assessed approximately using factor analysis (Jorion, 1990). The method consists of regressing the stock market return of the particular industry or firm analyzed on exchange rate changes while controlling for overall stock market movements. The econometric model specification used in the analysis is:

$$
R_{i, t}=a_{0}+a_{1} R_{s, t}+a_{2} R_{m, t}+\varepsilon_{i, t}
$$

where $R_{i, t}$ is the stock market return of firm or industry $i$ in period $t, R_{s, t}$ the rate of change of the Chilean peso exchange rate vis-à-vis the U.S. dollar, $R_{m, t}$ is the rate of the return of the Chilean stock market, and $\varepsilon_{i, t}$ is an independent and identically distributed error. The coefficient associated to changes of the exchange rate, $a_{1}$, measures the foreign exchange exposure of firm or industry $i$, or equivalently, the elasticity of its stock returns to changes in exchange rates.

Two caveats about factor analysis should be bear in mind. First, as noted by Adler and Dumas (1984), factor analysis is equivalent to a statistical decomposition of stock market returns and does not necessarily imply a causal relationship between returns and exchange rate changes. Second, the empirical method cannot explain how changes on firms' operating procedures affect their exchange rate exposure. If the coefficient $a_{1}$ is not different from zero, it does not necessarily imply negligible foreign exchange exposure. For instance, the firm may be hedging actively its foreign exchange exposure using derivatives or other operational techniques. Therefore, the firm offsets any impact exchange rate movements have on its stock market return.

The analysis includes the following sectors: consumer discretionary goods, consumer staples, financials, health care, industrials, materials, telecommunications, and utilities. Morgan Stanley Capital Indices (MSCI) for each sector and the overall market are used to calculate monthly stock market returns. The sample period analyzed is January 1995 to April 2004. Equation (1) was estimated for the full sample period as well as for two subperiods, January 1995 to December 1999, and January 2000-April 2004 using Ordinary Least Squares and correcting for serial correlation of the error term. Dividing the sample in two subsamples helps assessing changes in foreign exchange exposure that may be attributed to increased management of exchange rate risk at the sectoral level. It also allows examining the impact on foreign exchange rate exposure of the abandonment of the floating band in September 1999. 


\section{Box 2. What Factors Determine the Demand for Foreign Exchange Hedging}

Hedging foreign exchange risk is just one component of a firm's overall risk management program. Hedging foreign exchange risk is valuable if it helps reduce the costs of financial distress, decrease taxes, or avoid bad investment decisions arising from agency costs (Smith and Stulz, 1985).

Financial distress happens when a firm's income cannot cover its fixed expenses. Direct costs associated with financial distress are those linked to default, bankruptcy, reorganization, and/or liquidation. In addition, there are indirect costs associated with the firms' operations even if no default occurs. For instance, borrowing costs increased significantly to compensate for increased probability of default. Also, customer loyalty may decline causing sales, and hence, income to decline. Hedging reduces the likelihood of financial distress by reducing the volatility of foreign currency-denominated cash flows.

Foreign exchange hedging can decrease tax payments if the tax schedule is a convex function of income. In this case, smoothing pre-tax income lowers the average tax burden. Even in countries where the tax schedule is flat, tax preference items such as tax loss carry-forwards and investment tax credits create convexity, and hence, an incentive to hedge.

Finally, different stakeholders in the firm, that is shareholders, debt-holders, and managers, have conflicting objectives that may lead to sub-optimal investment decisions. For instance, managers' compensation largely depends on the performance of the firm. As a result, managers may demand a premium be added to their wages or bypass projects they deem too risky. If the firm hedges its exposure, including that related to foreign currency-denominated cash flows, these problems are attenuated. Hedging also helps firms to increase their leverage by reducing borrowing costs since it assures potential bondholders of a reduced probability of financial distress. Hence, it becomes easier for firms to achieve an optimal capital structure. 


\section{Box 3. How Currency Derivatives Can Contribute to Destabilizing Exchange Rates during Periods of Distress}

A market maker that is a foreign currency payer in a forward contract can hedge the foreign exchange risk exposure by creating a reverse position synthetically in the money market. This involves borrowing the present value of the notional amount of the contract in domestic currency, exchanging it for foreign currency in the spot market today and depositing it in a money market account. When the contract matures, the principal and interest earned on the foreign currency deposit offset the foreign currency payment, while the domestic currency received is used to pay the domestic currency loan. Hence, in the midst of a financial panic, hedging activity by market makers may lead to upward pressure on interest rate and downward pressure on the domestic currency beyond that justified solely by economic fundamentals. This situation was experienced in Brazil in mid-2002, when uncertainty about the presidential elections boosted demand for currency hedging in the forward market. Substantial selling pressure in the spot market drove the Brazilian real and domestic interest rates to all time highs.

End-users who want to hedge foreign exchange risk have to buy foreign currency call options, or equivalently, domestic currency put options. Market makers selling foreign currency call options to end-users can hedge their short position using delta hedging. Delta hedging requires requires buying an amount of foreign currency proportional to the notional amount of the option contract. The amount of foreign currency is determined by the "delta" of the contract, a measure of the sensitivity of the option price to changes of the exchange rate. When the exchange rate depreciates, that is, the foreign currency becomes more expensive relative to the domestic currency, the delta of the option increases. Therefore, the market maker is forced to buy increasingly larger amounts of foreign currency, which in turn, puts additional downward pressure on the domestic currency. ${ }^{11}$

${ }^{11}$ See Briys et al (1998) for a comprehensive explanation of how to manage option positions. 


\section{References}

Adler, Michael, and Bernard Dumas, 1984, "Exposure to Currency Risks: Definitions and Measurement,” Financial Management, Vol. 13 (Summer), pp. 41-50.

Alarcón, Felipe, Jorge Selaive, and José Villena, 2004, “El Mercado de Derivados Cambiarios Chileno” (unpublished, Santiago: Banco Central de Chile).

Anidjar, Martin, 2002, “Chile,” in Local Markets Guide (New York: JPMorgan).

Bank for International Settlements, 2002, Triennial Central Bank Survey 2001 (Basle).

Bryis, Eric, Mondher Bellalah, Huu Minh Mai, and Francois de Varenne, 1998, Options, Futures and Exotic Derivatives. Theory, Application, and Practice (Chichester: John Wiley and Sons).

Caballero, Ricardo J., Kevin Cowan, and Jonathan Kearns, 2004, “Fear of Sudden Stops: Lessons from Australia and Chile” (unpublished, Cambridge: Massachusetts Institute of Technology).

Conrad, Jennifer, 1989, “The Price Effect of Option Introduction,” Journal of Finance, Vol. 44, pp. 487-498.

Detemple, Jerome, and Philippe Jorion, 1990, “Option Listing and Stock Returns: An Empirical Analysis,” Journal of Banking and Finance, Vol. 14, pp. 781-801.

Diario Estrategia, 2004, “Los Productos Financieros Para Cubrirse de las Variaciones del Dólar,” February 16 (Santiago de Chile).

Dodd, Randall, 2001, “The Role of Derivatives in the East Asian Financial Crisis,” Special Policy Report 1 (Washington, DC: Derivatives Study Center).

Dominguez, Kathryn M.E., and Linda L. Tesar, 2001, “Exchange Rate Exposure,” NBER Working Paper 8453 (Cambridge, MA: National Bureau of Economic Research).

Edison, Hali, 2003, “Are Foreign Exchange Reserves in Asia Too High?,” in World Economic Outlook, September 2003 (Washington, DC: International Monetary Fund).

Fernandez, Viviana, 2001, “The Derivatives Market in Latin America with an Emphasis on Chile,” working paper, Departamento de Ingenieria Industrial (Santiago: Universidad de Chile).

Garman, Mark B., and Stephen W. Kohlhagen, 1983, "Foreign Currency Options Values," Journal of International Money and Finance, Vol. 2, pp. 231-237. 
Gutierrez, Eva, 2004, “The Banking Sector: Risk Exposures and Industry Practices Conducive to Effective Risk Based Supervision,” Special Issues Paper, Financial Sector Assessment Program - Chile (Washington: International Monetary Fund and World Bank).

Hagelin, Niclas, 2003, “Why Firms Hedge with Currency Derivatives: An Examination of Transaction and Translation Exposure,” Applied Financial Economics, Vol. 13, pp. 55-69.

Hakkarainen, Anti, Nathan Joseph, Eero Kasanen, and Vesa Puttonen, 1998, “The Foreign Exchange Exposure Management Practices of Finnish Industrial Firms,” Journal of International Financial Management and Accounting, Vol. 9, pp. 34-57.

International Monetary Fund, and World Bank, 2004, Financial Sector Assessment Program Chile, Aide Memoire (Washington, DC).

International Monetary Fund, 1998, International Capital Markets. Developments, Prospects, and Key Policy Issues (Washington, D.C.).

, 2002, Global Financial Stability Report. Market Developments and Issues (Washington, D.C.).

Jalilvand, Abolhassan, 1999, "Why Firms Use Derivatives: Evidence from Canada,” Revue Canadienne des Sciences de l’Administration, Vol. 16, pp. 213-228.

Jorion, Philippe, 1990, “The Exchange-Rate Exposure of U.S. Multinationals,” Journal of Business, Vol. 63, pp. 331-346.

Mendelson, Irit, and Thomas Glaessner, 2004, “Hedging - Towards More Efficient Risk Management” (unpublished).

Moguilllansky, Graciela, 2002, “Non-Financial Corporate Risk Management and Exchange Rate Volatility in Latin America,” Discussion Paper No. 2002/30, World Institute for Development Economics Research, United Nations University.

Nguyen, Hoa, and Robert Faff, 2002, “On the Determinants of Derivative Usage by Australian Companies,” Australian Journal of Management, Vol. 27, pp. 1-24.

Romo, Javier, Claudia Castro, and Karim Abdel-Mootal, 2002, Chile Local Markets (New York: Morgan Stanley).

Smith, Clifford W., and Rene M. Stulz, 1985, “The Determinants of Firms’ Hedging Policies,” Journal of Financial and Quantitative Analysis, Vol. 20, pp. 391-405.

Steinherr, Alfred, 2000, Derivatives: The Wild Beast of Finance (New York: John Wiley and Sons). 